\title{
PRiVATIZING SOCIAL SECURITY UNDER BALANCED-BUDGET CONSTRAINTS: A POLITICAL-ECONOMY APPROACH
}

\author{
ASSAF RAZIN \\ EFRAIM SADKA
}

CESIFO WORKING PAPER NO. 1039

CATEGORY 1: PUBlic FinANCE

SEPTEMBER 2003

Presented At $3^{\text {RD }}$ Norwegian-German Seminar on Public EConomics, June 2003

An electronic version of the paper may be downloaded

- from the SSRN website: www.SSRN.com

- from the CESifo website: www.CESifo.de 


\title{
PRIVATIZING SOCIAL SECURITY UNDER BALANCED-BUDGET CONSTRAINTS: A POLITICAL-ECONOMY APPROACH
}

\begin{abstract}
The aging of the population shakes the public finance of pay-as-you-go social security systems. We develop a political-economy framework in which this demographic change leads to the downsizing of the social security system, and, as a consequence, to the emergence of supplemental individual retirement programs. Making the balanced-budget rule (of the type of the Stability and Growth Pact in the EU) more flexible, to accommodate a one-shot cost of the social security reforms, is shown to facilitate the political-economy transition from a national to a private pension system, through an endogenously determined shift in the politicaleconomy equilibrium.

JEL Code: G1.

\author{
Assaf Razin \\ Tel Aviv University \\ Economics Department \\ 69978 Tel Aviv \\ Israel \\ razin@post.tau.ac.il
}

\author{
Efraim Sadka \\ Tel-Aviv University \\ The Eitan Berglas School of Economics \\ Naftali Building \\ 69978 Tel-Aviv \\ Israel
}

sadka@post.tau.ac.il

Some of the work on this paper was done while the authors were visiting the Economic Policy Research Unit (EPRU) at the University of Copenhagen, February, 2003. We also acknowledge the sponsoring RTN project "The Analysis of International Capital Markets: Understanding Europe's Role in the Global Economy." We benefitted from discussions in a seminar presentation at the Hebrew University; in particular, we wish to thank Elchanan BenPorath, Sergui Hart, Oded Galor, Motty Perry, and Eytan Sheshinski.
\end{abstract}




\section{Introduction}

The economic viability of national old-age security systems has been increasingly deteriorating in the wake of aging of the population. The demographers Oepper and Vaupel (2002) pose the question, "is life expectancy approaching its limit?" Their answer: "Many... believe it is. The evidence suggests otherwise... For 160 years, best-performance life expectancy has steadily increased by a quarter of a year per year, an extraordinary constancy of human achievement." Indeed the median age in Europe is forecasted to rise from 37.7 now to 52.7 in 2050 (The Economist, August 24th, 2002, p. 22). Similarly, the ratio of the elderly (aged 60 years and over) to the working-age population (aged 15-59 years) in Western Europe is expected to double from $20 \%$ in the year 2000 to $40 \%$ in the year 2050 (op. cit, p. 22). These demographic trends are driven mainly by declining fertility rates: ${ }^{1}$

"At present, West European countries are following what seems to be a normal demographic path: As they became richer after the 1950s, so their fertility rates fell sharply. The average number of children borne by each woman during her lifetime fell from well above the "replacement rate" of 2.1 - the rate at which the population remains stable - to less than 1.4 now" (op. cit., p. 11).

Evidently, aging has far-reaching implications for national pension systems. As put by The Economist (August 3rd, 2002, p. 23):

"As its people grow grayer, Europe's state pensions systems will go deeper into the red. Germany and Italy are trying to push the private-sector alternative. It is not easy...".

More concretely, for Germany:

\footnotetext{
${ }^{1}$ The U.S. has experienced a similar trend until recently, but then the fertility rate started to rise sharply.
} 
"Seven-tenths of German pensions come from a state scheme with roots is Bismarck's day. It is financed mainly by a levy on wages, $19.1 \%$ this year, half paid by workers and half by employers. But, as all over Europe, the demographics are grim. Today, there are 2.8 Germans aged 20 - 59 to support each pensioner. By 2030 there could be half as many. And the state can't just fork out money to fill the gap" (op. cit., p. 23).

And similarly, in Italy:

"The government's strategy is to get private pension schemes and funds, now embryonic, working properly first. Then, it hopes, it will be politically able to tackle the financing of the pay-as-you-go state system. But Italy cannot afford to wait. Its state's spending on pensions is more than 14\% of GDP, almost double the European Union average. Every year, payouts far exceed contributions by workers and employers" (op. cit., p. 24).

Indeed, the aging of the population raises the burden of financing the existing pay-as-yougo, national pension (old-age security) systems, because there is a relatively falling number of workers, that have to bear the cost of paying pensions, to a relatively rising number of retirees. Against this backdrop, there arose proposals to privatize social security, as a solution to the economic sustainability of the existing systems. This, by and large, means a shift from the current pay-as-you-go systems to individual retirement accounts (or fully-funded systems). A supposedly added benefit to such a shift is the better return on the contributions to individual accounts than to a pay-as-you-go national pension systems. However, a careful scrutiny of the argument reveals that it is flawed, as neatly demonstrated by Paul Krugman (2002):

Imagine an overlapping-generations model with just one young (working) person and one old (retired) person in each period - each individual lives for two periods. Suppose there is a pay-as- 
you-go, national pension system by which the worker contributes one euro to finance the pension benefit of one euro paid to the retiree. Each young person contributes one euro when young and working and receives one euro upon retirement. Evidently, the young person earns zero return on her contribution to the national pay-as-you-go, old-age security system. If, instead, the young person were to invest her one euro in an individual account, she would have earned the real market rate of return of, say, $100 \%$, allowing her a pension of two euros at retirement. (Recall that the average length of time between the first period of her life, in which she works, and the second period of her life, in which she is a pensioner, could be something like 30 years; so that a real rate of return of $100 \%$ between these two periods is not exorbitant.) Is the young person better off with this transition from pay-as-you-go systems to individual retirement accounts? Not if the government still wishes to honor the existing "social contract" (or political norm) to pay a pension benefit of one euro to the old at the time of the transition. In order to meet this liability, the government can issue a debt of one euro. The interest to be paid by the government on this debt at the market rate of $100 \%$ will be one euro in each period, starting from the next period ad infinitum. Hence the young person will be levied a tax of one euro in the next period when old, to finance the interest payment. Thus, her net-of-tax balance in the individual account will only be one euro, implying a zero net-of-tax return in the individual account; the same return as in the national, pay-as-you-go system.

And what if the individual invests the one euro in the equity market and gets a better return than the $100 \%$ which the government pays on its debt? If the capital markets are efficient, the higher equity return (relative to the government bond rate) reflects nothing else but a risk premium. That is, the equity premium is equal to the risk premium through arbitrage. Therefore, 
equity investment offers no gain in risk-adjusted return over government bonds. And if markets

are inefficient, then the government can, as a general policy, issue debt in order to invest in the equity market, irrespective of the issue of replacing social security by individual retirement accounts. $^{2},{ }^{3}$

Nevertheless, the increased fragility of national pay-as-you-go pension, caused by the aging of the population, raises doubts among the young about whether the next generations will continue to honor the implicit intergenerational social contract, or the political norm, according to which, "I pay now for the pension benefits of the old, and the next young generation pays for my pension benefits, when I get old". These doubts are, after all, not unfounded, for there will indeed be

\footnotetext{
${ }^{2}$ Greg Mankiw (Fortune Magazine, March 15, 1999) puts this argument this way:" Having trouble saving for your retirement? Try this simple solution: Borrow some money at $7 \%$, buy stocks that return 10\%, and pocket the $3 \%$ difference. Still running short? Don't worry-just do it again.

This is, of course, ridiculous advice. Buying equities with borrowed money is a risky strategy, and no one should do it without understanding those risks.

So let's consider the downside. Suppose the federal government put some of the Social Security trust fund in equities. Now suppose that the next decade turns out less like the early 1990s and more like the early 1930s, when the Dow Jones industrial average fell from 381 to 41-or like Japan today, where the stock market is still at less than half the level it reached a decade ago. What would happen?

Clearly, Social Security would be in big trouble. Not only would baby-boomers be starting to retire, automatically boosting government spending on retirement programs, but the market collapse would likely coincide with a recession, reducing tax revenue. With the trust fund drained by low stock prices, Social Security benefits would almost certainly be cut. A lot.

Although the downside risk is far from negligible, it could still be a risk worth taking. Buying stocks rather than bonds does work out, on average, and we would be irrational to avoid risk at all costs. But there are several reasons to think it's a bad bet.

First, it seems an unlikely coincidence that the proposal (to go short on equities and long on government bonds) comes on the heels of several years (the 1990s) of truly exceptional stock returns. If we take a look at history, however, the stock market isn't nearly as impressive: In the 19th century, the average premium for investing in stocks over bonds was less than $3 \%$.

Second, the stock market's historical performance reflects a large amount of good luck. We live in the world's richest country, at the end of the most prosperous century ever; it should come as no surprise that the market has done so well. The future may give us a similarly lucky draw, but let's not count on it.

Third, some economists see the large historical equity premium as an anomaly that's already been corrected. Most measures of stock market valuation are now at historical extremes. Perhaps this is because investors, realizing stocks were undervalued in the past, have corrected the problem. If so, stocks are unlikely to keep outperforming bonds by the same margin."

See, however, Diamond and Jeanakoplos (1999) for a useful analysis of the portfolio diversification advantages from investing retirement savings in the equity market in certain circumstances.

${ }^{3}$ See, however, Diamond and Jeanakoplos (1999) for a useful analysis of the portfolio diversification advantages from investing retirement savings in the equity market in certain circumstances.
} 
more pensioners per each young worker of the next generation, and hence each one of the young workers will have to pay more in order to honor the implicit social contract. With such doubts, the political power balance may indeed shift towards scaling down the pay-as-you-go system, encouraging the establishment of supplemental individual retirement accounts. ${ }^{4}$ Such accounts are, by their very nature, fully funded, so that they are not directly affected by the aging of the population. ${ }^{5}$ Naturally, the existing old generation opposes any scaling down of the pay-as-yougo system, because it stands to lose pension benefits (without enjoying the reduction in the social security contributions). This opposition can, however, be softened, or altogether removed, if the government creates a budget deficit in order to support the social security system and allow it not to scale down the pension benefits to the current old, so as to fully offset the reduction in social security contributions, or even allow it to maintain these benefits intact. (Of course, this deficit will be carried over to the future, with its debt service smoothed over the next several generations.) However, here may stand in the way some self-imposed restrictions such as the Stability and Growth Pact in the EU, which put a ceiling on the current fiscal deficit. ${ }^{6}$

In any event, the current systems are by and large insolvent because of the aging of the population so either social security taxes are increased exorbitantly or else government debt could, according to some projections, reach $150 \%$ of national income in the EU at large by 2050 ,

\footnotetext{
${ }^{4}$ The welfare state may also come under attack because of international tax competition brought about by globalization; see, for instance, Sinn (1990) and Lassen and Sorensen (2002). On the other hand, Rodrik (1998) advances an opposite hypothesis that exposure to foreign trade, another facet of globalization, generates greater income uncertainties; consequently, the public demand for social insurance rises.

${ }^{5}$ Naturally , the aging of the population has some bearing on individual retirement accounts too through the general-equilibrium effects on the return to capital (stemming from the induced change in the capital-labor ratio).

${ }^{6}$ The idea of the Stability and Growth Pact is to prevent governments from running loose fiscal policies at the expense of the other euro-area countries. This could happen through either higher interest rates, if the ECB offset the fiscal laxity with tight monetary policy, or by higher risk premium on euro-area government bonds. But, to the extent that the Pact in its current version is an impediment to social security reform, it can cause the deterioration of the fiscal stance in the future, and the social security system will move into deficits. Other notable limitations of the Pact are described in Calmfors et al (2003).
} 
and $250 \%$ in Germany and France. Recall that the debt target ceiling in the pact is only $60 \%$ !

In this paper we develop an analytical model in which a pay-as-you-go, old-age security system is designed as a political-economy equilibrium. We then investigate how the aging of the population can shift the equilibrium towards scaling down this fiscal system (thereby encouraging the emergence of individual retirement accounts). We further examine how lifting the ceiling on fiscal deficits can politically facilitate such a scaling down of pay-as-you-go systems. ${ }^{7}$

The organization of the paper is as follows. Section 2 develops a political-economy framework for determining the social security system. Section 3 considers the effect of aging on the socialsecurity system. Section 4 analyzes the effect of making the balanced-budget rule more flexible. Section 5 concludes.

\section{Political-Economy Architecture Of Social Security: A Simple Framework}

Consider a standard overlapping-generations model in which each generation lives for two periods: a working period and a retirement period. Following Saint-Paul (1994) and Razin and Sadka (1995), we assume a stylized economy in which there are two types of workers: skilled workers who have high productivity and provide one efficiency unit of labor per unit of labor time, and unskilled workers who provide only $q<1$ efficiency units of labor per unit of labor time. Workers have one unit of labor time during their first period of life, but are born without skills and thus with low productivity. Each worker chooses whether to acquire an education and become a

\footnotetext{
${ }^{7}$ Razin ,Sadka and Swagel (2002a) deal with a different issue related to aging populations. They analyze how the willingless of a falling number of young workers to support an increasing number of retirees is affected by aging.
} 
skilled worker, or else remain unskilled. After the working period, individuals retire, with their consumption funded by private savings and social security pension, discussed below.

There is a continuum of individuals, characterized by an innate ability parameter, $e$ which is the time needed to acquire skill. By investing $e$ units of labor time in education, a worker becomes skilled, after which the remaining $(1-e)$ units of labor time provide an equal amount of effective labor in the balance of the first period. Less capable individuals require more time to become skilled and thus find education more costly in terms of lost income (education is a full-time activity). We assume positive pecuniary costs of acquiring skills, $\gamma$, which is not tax deductible. ${ }^{8}$ The cumulative distribution function of innate ability is denoted by $G($.$) with the$ support being the interval $[0,1]$. The density function is denoted by $g=G^{\prime}$.

If an individual with an innate ability level (henceforth an e-individual) acquires skill, then her income is $(1-\tau) w(1-e)-\gamma$, whereas if she remains unskilled her income is $(1-\tau) q w$, where $w$ is the wage rate per efficiency unit of labor and $\tau$ is the social security contribution (tax) rate. Therefore, there exists a cutoff level, $e^{*}$, such that those with education-cost parameter below $e^{*}$ will invest in education and become skilled, whereas everyone else remains unskilled. The cutoff level is determined by an equality between the return to education and the cost of education (including foregone income):

$$
(1-\tau) w\left(1-e^{*}\right)-\gamma=(1-\tau) q w .
$$

Rearranging terms gives the cutoff level in the education decision:

\footnotetext{
${ }^{8}$ This is a realistic assumption. Unlike corporations for which depreciation of capital is deductible, for individuals the pecuniary cost of investment in human capital is not.
} 


$$
e^{*}=1-q-\gamma /[(1-\tau) w]
$$

To obtain analytical results, we use a specification in which factor prices are exogenously determined. This specification breaks any income links between generations, except for explicitly determined intergenerational transfers that are explained later. To simplify, we assume a linear production function in which output, Y, is produced using labor, L, and capital, K:

$$
Y=w L+(1+r) K
$$

The wage rate, $w$ and the gross (before depreciation) rental price of capital, $1+r$, are determined by the marginal productivity conditions for factor prices:

$$
w=\partial Y / \partial L \text { and } 1+r=\partial Y / \partial K
$$

These conditions are already substituted into the production function. For simplicity, we assume that capital fully depreciates at the end of the production process. The linearity of the production function can arise as an equilibrium outcome through either international capital mobility or factor price equalization in the presence of goods trade. The two types of labor are assumed to be perfect substitutes in production in terms of efficiency units of labor input.

We assume that the population grows at a rate of $n$. Labor supply of each individual is assumed to be fixed, so that the social security tax does not distort the individual labor-supply decisions, at the margin. The aggregate labor supply does, however, depend on the income tax rate, as this affects the cut-off ability, $e^{*}$, and thus the mix of skilled and unskilled individuals in 
the economy. This distortion keeps the tax rate from being driven up to $100 \%$. At the current period the aggregate labor supply is given by:

$$
\begin{aligned}
L & =\left\{\int_{0}^{e^{*}}(1-e) d G+q\left[1-G\left(e^{*}\right)\right]\right\} N_{o}(1+n) \\
& =\ell\left(e^{*}\right) N_{0}(1+n),
\end{aligned}
$$

where $N_{o}(1+n)$ is the size of the working-age population at present $\left(N_{o}\right.$ is the number of young individuals born in the preceding period), and $\ell\left(e^{*}\right)=\int_{0}^{e^{*}}(1-e) d G+q\left[1-G\left(e^{*}\right)\right]$ is the average labor supply (per worker) in the current period.

There is a pay-as-you-go, old-age social security system by which the taxes collected from the young (working) population are earmarked to finance a pension-benefit to the old (retired) population. Thus, the benefit $\left(b_{t}\right)$, paid to each individual at present, must satisfy the following pay-as-you-go budget constraint:

$$
b N_{0}=\tau w L=\tau w \ell\left(e^{*}\right) N_{o}(1+n)
$$

where $\tau$ is the social security tax at present. Dividing through by $N_{o}$ yields an explicit formula for the pension benefit:

$$
b=\tau \omega l\left(e^{*}\right)(1+n) .
$$

Votes are repeated every period. In each period, the benefit of the social-security system accrues only to the old, whereas the burden (the social-security taxes) are borne by the young. Then, one may wonder why would not the young, who outnumber the old with a growing population, drive the tax and the benefit down to zero in a political-economy equilibrium. We appeal 
to a sort of an implicit intergenerational social contract which goes like this: ${ }^{9}$ "I, the young, pay now for the pension benefits of the old; and you, the young of the next generation, will pay for my pension benefit, when I grow old and retire". This implicit intergenerational contract could be an outcome of an intergenerational game, with trigger strategies, as shown in Cooley and Soares (1999a and 1999b). The young believe that if they do not pay the old a pension benefit, then the next young generation will punish them by not providing for their pensions. With such a contract in place, the young at present are willing to politically support a social security tax, $\tau$, which is earmarked to pay the current old a pension benefit of $b$, because they expect the young generation in the next period to honor the implicit social contract and pay them a benefit $\alpha b$. The parameter $\alpha$ is assumed to depend negatively on the share of the old in the population. If the current young will each continue to bring $n$ children, then the share of the old will not change in the next period and $\alpha$ is expected to be one. But if fertility falls and the share of the old in the next period rises relative to the present, then $\alpha$ is expected to fall below one. This is because the young believe that if fertility falls in the future, the next young generation will either find it harder or will be plainly reluctant to continue to support the old (the current) young at the current level. ${ }^{10}$

Because factor prices are constant over time, current saving decisions will not affect the rate of return on capital that the current young will earn on their savings. Hence, the dynamics in this model are redundant. For any social security tax rate, $\tau$, equations (1) and (4) determine the functions $e^{*}=e^{*}(\tau)$ and $b=b(\tau)$. Denote by $W(e, \tau, \alpha)$ the lifetime income of a young

\footnotetext{
${ }^{9}$ See Cooley and Soares (1999a, 1999b) for a game-theoretic formulation of such an inter-generational contract.

${ }^{10}$ See also Razin and Sadka (2002a).
} 
e-individual:

$$
W(e, \tau, \alpha)=\left\{\begin{array}{c}
(1-\tau) w(1-e)-\gamma+\alpha b(\tau) /(1+r) \quad \text { for } e \leq e^{*}(\tau) \\
(1-\tau) w q+\alpha b(\tau) /(1+r) \quad \text { for } e \geq e^{*}(\tau) .
\end{array}\right.
$$

In each period, the political-economy equilibrium for the social security tax, $\tau$ (and the associated pension benefit, $b$ ), is determined by majority voting among the young and old individuals who are alive in this period. The objective of the old is quite clear: so long as raising the social security tax rate, $\tau$, generates more revenues, and consequently, a higher pension benefit, $b$, they will vote for it. However, voting of the young is less clear-cut. Because a young individual pays a tax bill of $\tau w(1-e)$ or $\tau w q$, depending on her skill level, and receives a benefit of $\alpha b /(1+r)$, in present value terms, she must weigh her tax bill against her benefit. She votes for raising the tax rate, if $\partial W / \partial \tau>0$, and for lowering it, if $\partial W / \partial \tau<0$. Note that:

$$
\partial^{2} W(e, \tau, \alpha) / \partial e \partial \tau=\left\{\begin{array}{l}
w \text { for } e<e^{*}(\tau) \\
0 \text { for } e>e^{*}(\tau)
\end{array}\right.
$$

Therefore, if $\partial W / \partial \tau>0$ for some $e_{o}$, then $\partial W / \partial \tau>0$ for all $e>e_{o}$; and, similarly, if $\partial W / \partial \tau<0$ for some $e_{o}$, then $\partial W / \partial \tau<0$ for all $\mathrm{e}<e_{0}$. This implies that if an increase in the social security tax rate benefits a particular young (working) individual (because the increased pension benefit outweighs the increase in the tax bill), then all young individuals who are less able than her (that is, those who have a higher cost-of-education parameter, $e$ ), must also gain from this tax increase. Similarly, if a social security tax increase hurts a certain young individual (because the increased pension benefit does not fully compensate for the tax hike), then it must also hurt 
all young individuals who are more able than her.

As was already pointed out, the old always opt for a higher social security tax. But as long as $n>0$, the old are outnumbered by the young. To reach an equilibrium, the bottom end of the skill distribution of the young population joins forces with the old to form a pro-tax coalition of $50 \%$ of the population,whereas the top end of the skill distribution of the young population forms a counter, anti-tax coalition of equal size. In determining the outcome of majority voting the decisive voter must be a young individual, with an education-cost index denoted by $e_{M}$, such that the young who have an education-cost index below $e_{M}$ (namely, the anti-tax coalition) form $50 \%$ of the total population. The political-economy equilibrium tax rate maximizes the lifetime income of this median voter.

Formally, $e_{M}$ is defined as follows. There are $N_{o}(1+n) G\left(e_{M}\right)$ young individuals with costof-education parameter $e \leq e_{M}$ (more able than the median voter), and $N_{o}(1+n)\left[1-G\left(e_{M}\right)\right]$ young individuals with cost-of-education parameter $e \geq e_{M}$ (less able than the median voter). There are also $N_{o}$ retired individuals at present who always join the pro-tax coalition. Hence, $e_{M}$ is defined implicitly by:

$$
N_{0}(1+n) G\left(e_{M}\right)=N_{o}(1+n)\left[1-G\left(e_{m}\right)\right]+N_{o}
$$

Dividing this equation by $N_{o}$ and rearranging terms yield the cost-of-education parameter for the median voter:

$$
e_{M}=G^{-1}\left[\frac{2+n}{2(1+n)}\right]
$$

As noted, the political equilibrium tax rate, $\tau$, denoted by $\tau_{o}\left(e_{M}, \alpha\right)$, maximizes the 
lifetime income of the median voter:

$$
\tau_{o}\left(e_{M}, \alpha\right)=\arg \max _{\tau} W\left(e_{M}, \tau, \alpha\right)
$$

This equilibrium tax rate is implicitly defined by the first-order condition:

$$
\frac{\partial W\left[e_{M}, \tau_{0}\left(e_{M}, \alpha\right), \alpha\right]}{\partial \tau} \equiv B\left[e_{M}, \tau_{0}\left(e_{M}, \alpha\right), \alpha\right]=0
$$

and the second-order condition is:

$$
\frac{\partial^{2} W\left[e_{M}, \tau_{0}\left(e_{M}, \alpha\right), \alpha\right]}{\partial \tau^{2}}=B_{\tau}\left[e_{M}, \tau_{o}\left(e_{M}, \alpha\right), \alpha\right] \leq 0
$$

where $B_{\tau}$ is the partial derivative of $B$ with respect to its second argument.

Recent models [see Cooley and Soarez (1999a) and Bohn (1999)] have used an explicit game-theoretic reasoning to address the issue of the survivability of the pay-as-you-go social security system. This literature demonstrates the existence of an equilibrium in an overlappinggenerations model with social security as a sequential equilibrium in an infinitely repeated voting game. The critical support mechanism is provided by trigger strategies. As put by Bohn:

"The failure of any cohort to adhere to the proposed equilibrium triggers a negative change in voters' expectations about future benefits that destroys social security. Since survival and collapse are discrete alternatives, trigger strategy models provide a natural definition of what is meant by social security being viable."

To support social security as a sequential equilibrium, there is a very simple condition that must be fulfilled. For the median voter, the present value of future benefits exceeds the value of 
social security contributions until retirement. This condition is easily satisfied in our overlapping generations model.

\section{Social Security under Strain: A ging Population}

The aging population puts the pay-as-you-go, old-age social security systems under strain. The burden of financing the pension benefits to the old falls on fewer young shoulders, when population ages, as we have already pointed out. Thus, if the fertility of the current young falls below the fertility rate $(n)$ of their parents, then the share of the old in the next period will rise. The current young expects the next young generation to reduce the benefit it pays to the old (current young) generation. ${ }^{11}$ That is, the current young generation perceives a smaller $\alpha$.

In order to find the effect of aging on social security, we investigate the effect of a decline in $\alpha$ on the equilibrium social security tax rate, $\tau_{o}\left(e_{M}, \alpha\right)$. Differentiate equation (9) totally with respect to $\alpha$ to conclude that

$$
\frac{\partial \tau_{o}\left(e_{M}, \alpha\right)}{\partial \alpha}=-\frac{B_{\alpha}\left[e_{M}, \tau_{0}\left(e_{M}, \alpha\right), \alpha\right]}{B_{\tau}\left[e_{M}, \tau_{0}\left(e_{M}, \alpha\right), \alpha\right]},
$$

where $B_{\alpha}$ is the partial derivative of $B$ with respect to its third argument. Because $-B_{\tau}$ is nonnegative [see the second-order condition (10)], it follows that the sign of $\partial \tau_{o} / \partial \alpha$ is the same as the sign of $B_{\alpha}$. It also follows from equation (9) that $B_{\alpha}=\partial^{2} W / \partial \alpha \partial \tau$. Employing equation

\footnotetext{
${ }^{11}$ In the appendix we analyze in our framework the effect of aging on the size of the welfare state.
} 
(5) we find that:

$$
B_{\alpha}\left[e_{M}, \tau_{o}\left(e_{M}, \alpha\right), \alpha\right]=\frac{\partial^{2} W\left[e_{M}, \tau_{o}\left(e_{M}, \alpha\right), \alpha\right]}{\partial \alpha \partial \tau}=\frac{1}{1+r} \frac{d b\left[\tau_{0}\left(e_{M}, \alpha\right)\right]}{d \tau}
$$

Naturally, no one will vote for raising the social security tax if $d b / d t<0$, because in such a case, the pension-benefit falls when the social security tax is raised. Put differently, a politicaleconomy equilibrium will never be located on the "wrong" side of the Laffer curve, where a tax rate hike lowers revenue. This can also be seen formally. From equation (5),

$$
B(e, \tau, \alpha)=\frac{\partial W(e, \tau, \alpha)}{\partial \tau}=\left\{\begin{array}{c}
-w(1-e)+\frac{\alpha}{1+r} \frac{d b(\tau)}{d \tau} \text { for } e 5 e^{*}(\tau) \\
-w q+\frac{\alpha}{1+r} \frac{d b(\tau)}{d \tau} \text { for } e=e^{*}(\tau)
\end{array}\right.
$$

so that, when the lifetime income of the median voter is maximized that is, when $B=0$ [see equation (9)], we have

$$
\frac{d b\left[\left(\tau_{0}\left(e_{M}, \alpha\right)\right]\right.}{d \tau}=\left\{\begin{array}{c}
w\left(1-e_{M}\right)(1+r) / \alpha \text { if } e_{M} 5 e^{*}(\tau) \\
w q(1+r) / \alpha \text { if } e_{M} \geq e^{*}(\tau)
\end{array}\right\} \geq 0
$$

Thus, it follows from equations (12) and (14), that $B_{\alpha}\left[e_{M}, \tau_{o}\left(e_{M}, \alpha\right), \alpha\right] \geq 0$, and hence, from equation (11), that

$$
\frac{\partial \tau_{o}\left(e_{M}, \alpha\right)}{\partial \alpha}>0
$$

We conclude that when the young population expects reduced social security benefits because of the aging of the populations (that is, when $\alpha$ falls), the public indeed votes for scaling down the 
social security system already at present (that is, for lowering $\tau$ and $b$ ). As a result, the young resort to supplemental old-age savings, such as individual retirement accounts. Naturally, the old are worse-off as a result of reducing $b$. But, they are outvoted by the young, whose attitude for lowering $\tau$ has turned stronger, following the reduction in the social security benefits that they will get.

\section{M aking the Balanced-Budget Rule M ore F lexible}

The old, naturally, continue to oppose the (partial) transition from a pay-as-you-go, old age social security system to individual retirement accounts, because they lose some of their pension benefits. They also have a strong moral claim that they contributed their fair share to the social security system, when they were young, but they receive at retirement less than what they paid when they were young. Their opposition, strengthened perhaps by being morally justified, can be accommodated, in part or in full, if the government is allowed to make a debt-financed transfer to the social security system, so as to allow the system to pay pension benefits in excess of the social security tax revenues. This deficit is carried forward to the future, and its debt-service is smoothed over the next few generations, so that its future tax implications for the current young generation is not significant. This, of course, requires relaxation of some restrictions of the sorts imposed by the Stabilization and Growth Pact in the EU during the transition from social security to individual retirement accounts.

For simplicity, suppose that the government makes a transfer at the exact amount that is required to keep the pension benefits of the current old intact, despite the reduction in the social security tax rate. Specifically, when $\tau$ falls, then the term $b$ in equation (4), that is financed 
by this $\tau$, falls as well. But we assume that the government compensates the old generation, so as to maintain the total pension benefits intact. Therefore, despite the fall in $b$, the old are indifferent to the reduction in $\tau$ (and, consequently, the reduction in b). Thus, the outcome of the majority voting is now effectively determined by the young only. The median voter is now a median among the young population only. This median voter has a lower cost-of-education index than before; that is, $e_{M}$ will fall.

In order to find the effect of the fall in $e_{M}$ on the political-economy equilibrium social security tax rate, $\tau_{0}\left(\mathrm{e}_{M}, \alpha\right)$, we follow the same procedure as in the preceding section, and conclude that:

$$
\frac{\partial \tau_{0}}{\partial e_{M}}=-\frac{B_{e_{M}}\left[e_{M}, \tau_{o}\left(e_{M}, \alpha\right), \alpha\right]}{B_{\tau}\left[e_{M}, \tau_{o}\left(e_{M}, \alpha\right), \alpha\right]},
$$

where, as before, the sign of $\partial \tau / \partial e_{M}$ is the same as the sign of $B_{e_{M}}$, because $B_{\tau} \leq 0$. Note that $B_{e_{M}}=\partial^{2} W / \partial e_{M} \partial \tau$, [see equation (9)], so that it follows from equation (5) that:

$$
B_{e_{M}}\left[e_{M}, \tau_{0}\left(e_{M}, \alpha\right), \alpha\right]=\left\{\begin{array}{l}
w \text { for } e_{M}<e^{*}(\tau) \\
0 \text { for } e_{M}>e^{*}(\tau)
\end{array} .\right.
$$

Thus, we conclude that $\partial \tau / \partial e_{M}$ is nonnegative: it is positive when the median voter is a skilled individual (that is, when $e_{M}<e^{*}$ ), and zero when the median voter is an unskilled individual (that is, when $e_{M}>e^{*}$ ). Hence, a decline in $e_{M}$ decreases (or leaves intact) the social security $\operatorname{tax} \tau_{o}\left(e_{M}, \alpha\right)$ and the associated benefit $b$.

The rationale for this result is straightforward. All unskilled people have the same lifetime income, regardless of their cost-of-education parameter, $e$. Therefore, the attitude towards the $(\tau, b)$ - pair is the same for all of them. Hence, the change in the median voter has no consequence 
on the outcome of the majority voting, when this median voter is an unskilled individual. For skilled individuals, lifetime income increases when the education-cost parameter, e, declines. Because the social security system is progressive with respect to the cost-of-education parameter, the net benefit from it (that is, the present value of the expected pension benefit minus the social security tax) declines, as lifetime income increases (that is, as $e$ falls). Therefore, a decline in the cost-of-education parameter of the median voter, $e_{M}$, lowers the political-economy equilibrium social security tax and pension benefit.

Thus, making the fiscal constraints, of the sorts imposed by the Stability and Growth Pact in the European Union, more flexible, may facilitate the political-economy transition from a national pay-as-you-go, old-age social security system to a fully funded private pension system. Such a transition, will, of course, improve the viability of the national system during and after the transition. But this comes at a cost of a lesser degree of income redistribution, an inherent feature of a national system.

\section{Conclusion}

The idea of the Stability and Growth Pact is to prevent governments from running loose fiscal policies at the expense of other euro-area countries. This spillover effect could happen through higher interest rates, if the ECB offset the fiscal laxity with tight monetary policy, or through higher risk premium on euro-area government bonds. But the Pact, as it is rigidly constructed, neglects long-term fiscal considerations. Because it creates political-economy impediments to social-security reforms which, if implemented, can improve the fiscal balance in the future.

We emphasize in this paper that the aging population shakes the public finance of pay-as- 
you-go, old-age social security systems. We demonstrate how in a political-economy framework these deteriorated balances lead to the down-sizing of the social system, and the emergence of supplemental individual retirement accounts. Indeed, Razin, Sadka and Swagel (2002) find a negative correlation between the dependency ratio (which increases with the aging of the population) and labor tax rates, in a 1970s-1990s sample that includes twelve Western European countries and the United States. Similarly, a negative correlation is found between the dependency ratio and per capita social transfers. These findings are consistent with the hypothesis of this paper that aging puts political-economic pressures so as to downsize pay-as-you-go, old-age national systems.

We illustrate these findings in Tables 1 and 2 which can be found in Razin, Sadka and Swagel (2002b). Table 1 contains results for reduced-form determinants of the tax rate on labor income. Table 2 contains results for reduced-form determinants of the per capita social transfers. The coefficients on the dependency ratio are negative and highly significant in both tables, as suggested by theory. 
Table 1: Determinants of Tax Rate on

Labor Income (dependent variable: labor tax rate, 146 observations) ${ }^{a}$

\begin{tabular}{|c|c|c|c|c|c|}
\hline & $(1)$ & $(2)$ & $(3)$ & $(4)$ & $(5)$ \\
\hline Government jobs/total employment & $\begin{array}{l}0.879 \\
(7.34)\end{array}$ & $\begin{array}{l}0.877 \\
(7.34)\end{array}$ & $\begin{array}{l}0.620 \\
(4.65)\end{array}$ & $\begin{array}{l}0.901 \\
(8.75)\end{array}$ & $\begin{array}{l}0.699 \\
(5.52)\end{array}$ \\
\hline Dependency ratio & $\begin{array}{c}-1.168 \\
(-7.59)\end{array}$ & $\begin{array}{c}-1.287 \\
(-7.05)\end{array}$ & $\begin{array}{c}-1.358 \\
(-7.76)\end{array}$ & $\begin{array}{l}-1.185 \\
(-6.96)\end{array}$ & $\begin{array}{l}-1.254 \\
(-7.53) \\
\end{array}$ \\
\hline Trade openness & $\begin{array}{c}-0.003 \\
(-0.10)\end{array}$ & $\begin{array}{l}-0.004 \\
(-0.16)\end{array}$ & $\begin{array}{l}-0.045 \\
(-1.65)\end{array}$ & $\begin{array}{l}0.008 \\
(0.34)\end{array}$ & $\begin{array}{l}-0.026 \\
(-0.99) \\
\end{array}$ \\
\hline Per capita GDP growth & $\begin{array}{l}-0.015 \\
(-0.25)\end{array}$ & $\begin{array}{l}-0.035 \\
(-0.55)\end{array}$ & $\begin{array}{c}-0.006 \\
(-0.10)\end{array}$ & $\begin{array}{l}0.027 \\
(0.45)\end{array}$ & $\begin{array}{l}0.042 \\
(0.72)\end{array}$ \\
\hline Rich/middle income share & $\begin{array}{c}-0.009 \\
(-0.18)\end{array}$ & $\begin{array}{c}-0.033 \\
(-0.62)\end{array}$ & $\begin{array}{c}-0.019 \\
(-0.37)\end{array}$ & $\begin{array}{l}-0.033 \\
(-0.68)\end{array}$ & $\frac{-0.022}{(-0.47)}$ \\
\hline Poor/middle income share & $\begin{array}{l}-0.065 \\
(-0.040) \\
\end{array}$ & $\begin{array}{c}-0.101 \\
(-0.61) \\
\end{array}$ & $\begin{array}{l}-0.059 \\
(-0.38)\end{array}$ & $\begin{array}{l}-0.017 \\
(-0.11)\end{array}$ & $\begin{array}{l}0.006 \\
(0.04)\end{array}$ \\
\hline Unemployment rate & & & $\begin{array}{c}0.327 \\
(3.73) \\
\end{array}$ & & $\begin{array}{l}0.259 \\
(3.07)\end{array}$ \\
\hline Immigrants/population & & $\begin{array}{c}-0.403 \\
(-1.20)\end{array}$ & $\begin{array}{c}-0.614 \\
(-1.89)\end{array}$ & $\begin{array}{c}-10.852 \\
(-4.88)\end{array}$ & $\begin{array}{c}-9.723 \\
(-4.45)\end{array}$ \\
\hline Medium + high education & & & & & \\
\hline immigrants/population & & & & $\begin{array}{c}19.043 \\
(4.75)\end{array}$ & $\begin{array}{c}16.679 \\
(8.37)\end{array}$ \\
\hline $\mathrm{R}^{2}$ & 0.652 & 0.656 & 0.690 & 0.708 & 0.728 \\
\hline
\end{tabular}

${ }^{a}$ All specifications include country fixed effects (coefficients not shown). The $t$ statistics are in parentheses. 
Table 2 shows results for the determinants of social transfers per person (in the common currency of real dollars). As with the labor tax rate, the dependency ratio has a significant negative effect.

Table 2 : Determinants of Per Capita Social Transfers

(dependent variable: social transfers per capita in real dollars, 146 observations) ${ }^{a}$

\begin{tabular}{|c|c|c|c|c|c|}
\hline & (1) & (2) & (3) & (4) & (5) \\
\hline Government jobs/total employment & $\begin{array}{c}4.359 \\
(3.13) \\
\end{array}$ & $\begin{array}{r}4.461 \\
(3.65)\end{array}$ & $\begin{array}{l}5.263 \\
(3.69) \\
\end{array}$ & $\begin{array}{l}4.618 \\
(3.84)\end{array}$ & $\begin{array}{l}5.825 \\
(4.14) \\
\end{array}$ \\
\hline Dependency ratio & $\begin{array}{c}-10.247 \\
(-5.72)\end{array}$ & $\begin{array}{l}-3.908 \\
(-2.09)\end{array}$ & $\begin{array}{l}-3.685 \\
(-1.96)\end{array}$ & $\begin{array}{l}-3.346 \\
(-1.81)\end{array}$ & $\begin{array}{c}-2.941 \\
(-1.59) \\
\end{array}$ \\
\hline Trade openness & $\begin{array}{l}-2.028 \\
(-6.73)\end{array}$ & $\begin{array}{l}-1.946 \\
(-7.35)\end{array}$ & $\begin{array}{c}-1.819 \\
(-6.29) \\
\end{array}$ & $\begin{array}{c}-1.879 \\
(-7.19) \\
\end{array}$ & $\begin{array}{c}-1.682 \\
(-5.87) \\
\end{array}$ \\
\hline Per capita GDP growth & $\begin{array}{l}-1.388 \\
(-1.95)) \\
\end{array}$ & $\begin{array}{l}-0.336 \\
(-0.52) \\
\end{array}$ & $\begin{array}{l}-0.425 \\
(-6.25) \\
\end{array}$ & $\begin{array}{l}0.009 \\
(0.01)\end{array}$ & $\begin{array}{l}-0.078 \\
(-0.12) \\
\end{array}$ \\
\hline Rich/middle income share & $\begin{array}{c}-2.399 \\
(-4.22) \\
\end{array}$ & $\begin{array}{c}-1.115 \\
(-2.07) \\
\end{array}$ & $\begin{array}{c}-1.159 \\
(-2.15) \\
\end{array}$ & $\begin{array}{l}-1.117 \\
(-2.11)\end{array}$ & $\begin{array}{c}-1.181 \\
(-2.24) \\
\end{array}$ \\
\hline Poor/middle income share & $\begin{array}{c}-7.350 \\
(-3.89) \\
\end{array}$ & $\begin{array}{l}-5.424 \\
(-3.21) \\
\end{array}$ & $\begin{array}{c}-5.554 \\
(-3.29) \\
\end{array}$ & $\begin{array}{c}-4.959 \\
(2.97) \\
\end{array}$ & $\begin{array}{c}-5.090 \\
(-3.07) \\
\end{array}$ \\
\hline Unemployment rate & & & $\begin{array}{c}-1.022 \\
(-1.09) \\
\end{array}$ & & $\begin{array}{l}-.514 \\
(-1.62) \\
\end{array}$ \\
\hline Immigrants/population & & $\begin{array}{c}21.583 \\
(6.30)\end{array}$ & $\begin{array}{c}22.244 \\
(6.39)\end{array}$ & $\begin{array}{c}-36.328 \\
(-1.51) \\
\end{array}$ & $\begin{array}{c}-42.945 \\
(-1.77) \\
\end{array}$ \\
\hline $\begin{array}{l}\text { Medium }+ \text { high education } \\
\text { immigrants/population }\end{array}$ & & & & $\underset{(2.43)}{105.532}$ & $\underset{(2.71)}{119.375}$ \\
\hline $\mathrm{R}^{2}$ & 0.497 & 0.616 & 0.620 & 0.633 & 0.641 \\
\hline
\end{tabular}

${ }^{a}$ All specifications include country fixed effects (coefficients not shown). The $t$ statistics are in parentheses.

These findings are consistent with the hypothesis of this paper that aging exerts political- 
economic pressure so as to downsize pay-as-you-go, old-age national systems. 


\section{R eferences}

[1] Bohn, Henning (1999). "Will Social Security and Medicare Remain Viable as the U.S. Population is Aging?" Carnegie-Rochester Series on P ublic Policy, 50 (June): 1-53.

[2] Calmfors, Lars, Giancarlo Corsetti (Chairman), John Flemming, Seppo Honkaphoja, John Kay, Willi Leibforitz, Gilles Saint-Paul, Hans-Werner Sinn, and Xavier Vives (2003), "Report on the European Economy 2003," CE Sifo, Munich.

[3] Cooley, Thomas and Jorge Soares (1999a), "A Positive Theory of Social Security Based on Reputation," J ournal of P olitical E conomy, 107 (1), 135-160.

[4] Cooley, Thomas and Jorge Soares (1999b), "Privatizing Social Security, Review of E conomic Dynamics, 2 (3), 731-755.

[5] Diamond, Peter A. and John Geanakoplos (1999), "Social Security Investment in Equities I: Linear Case", NBER Working Paper \#7103 (April).

[6] Oeppen, Jim and James W. Vaupel (2002), "Demography: Broken Limits to Life Expectancy," Science, 296, 1029-1031 (May 10th).

[7] Razin, Assaf, Efraim Sadka and Phillip Swagel (2002a), "The Aging Population and the Size of the Welfare State", J ournal of Political Economy, 110(4), August, pp. 900-918.

[8] Razin, Assaf and Efraim Sadka (2002b), "The Wage Gap and Social Security: Theory and Evidence," American Economic Review: Papers and Proceedings Vol. 92, No. 2, (May): 390-395. 
[9] Razin, Assaf and Efraim Sadka (1995), "Resisting Migration: Wage Rigidity and Income Distribution", American Economic Review: Papers and Proceedings May, 312-316.

[10] Saint-Paul, Gilles (1994), "Unemployment, Wage Rigidity and Returns to Education", European Economic Review, 38(3/4), April, 535-544. 


\section{APPENDIX: THE EFFECT OF AGING ON THE WELFARE STATE}

We note that the share of the old in the population at any period $t$ is $N_{0}(1+n)^{t-1} /\left[N_{0}(1+\right.$ $\left.n)^{t-1}+N_{0}(1+n)^{t}\right]=1 /(2+n)$. Thus, a decline in fertility (namely a decline in $n$ ) causes population to age (namely, to have a higher share of the old in the population). In order to find the effect of a change in $n$ on the political-economy equilibrium tax rate, note that equations (1) and (4) now define $e^{*}$ as a function $e^{*}(\tau)$ of $\tau$ and $b$ as a function $b(\tau, n)$ of $\tau$ and $n$. Also, equation (7) determines $e_{M}$ a a function $e_{M}(n)$ of $n$.

The lifetime income of a young $e$-individual can now be written as:

$$
W(e, \tau, n)=\left\{\begin{array}{c}
(1-\tau) \omega(1-e)-\gamma+\alpha b(\tau, n) /(1+r) \text { for } e 5 e^{*}(\tau) \\
(1-\tau) \omega q+\alpha b(\tau, n) /(1+r) \text { for } e=e^{*}(\tau)
\end{array}\right.
$$

Hence, condition (9) - the first-order condition for the political economy equilibrium tax rate, $\tau_{0}(n)-$ now becomes:

$$
\frac{\partial W\left[e_{M}(n), \tau_{0}[(n), n]\right.}{\partial \tau}=B\left[\tau_{0}(n), n\right]=0
$$

where

$$
B(\tau, n)=\left\{\begin{array}{c}
-\omega\left[1-e_{M}(n)\right]+\alpha b_{\tau}(\tau, n) /(1+r) \text { for } e 5 e^{*}(\tau) \\
-\omega q+\alpha b_{\tau}(\tau, n) /(1+r) \text { for } e=e^{*}(\tau)
\end{array}\right.
$$

We follow the same procedure as in the text, to get: 


$$
\frac{d \tau_{0}}{d n}=-\frac{B_{n}\left[\tau_{0}(n), n\right]}{B_{\tau}\left[\tau_{0}(n), n\right]} . \text { It therefore follows that }
$$

$$
\operatorname{Si} g n\left(\frac{d \tau_{0}}{d n}\right)=\operatorname{Si} g n\left(B_{n}\right) \text {. }
$$

Differentiating equation $\left(13^{\prime}\right)$ with respect to $n$ we find that:

$$
B_{n}\left[\tau_{0}(n), n\right]=\left\{\begin{array}{c}
\frac{d e_{m}}{d n}+\alpha b_{\tau n}\left[\tau_{0}(n), n\right] /(1+r) \text { for } e_{M} 5 e^{*}(\tau) \\
\alpha b_{\tau n}\left[\tau_{0}(n), n\right] \text { for } e_{M}=e^{*}(\tau)
\end{array}\right.
$$

Note from equation (4) that:

$$
b_{\tau n}=b_{\tau} /(1+n)>0
$$

by equation (14).

Suppose first that the decisive voter is an unskilled (young) individual, that is $e_{M}=e^{*}(\tau)$. Then $B_{n}>0$, and hence $d \tau_{0} / d n>0$. That is, aging (a decline in $n$ ) downscale the welfare state in this case. However, $d e_{M} / d n<0$ [see equation (7)], so that we cannot a priori sign $d \tau_{0} / d n$. Nevertheless, our regressions (see the concluding section) still indicate that $d \tau_{0} / d n>0$ : aging downscale the welfare state. ${ }^{12}$

\footnotetext{
${ }^{12}$ The rationale for this result is straightforward. As can be seen from equation (4), aging (namely, a decline in $n$ ) puts a higher burden on the shoulders of the young whose tax payments finance the welfare state. This effect works in the direction of making the decisive voter opt for a smaller tax (and pension benefit). But aging may also tilt the political power balance in favor of the pro-tax coalition: A decline in $n$ raises $e_{M}$ - the cost-of-education parameter of the decision voter. When the $e_{M}$-individual is unskilled, this does not change the choice of the decisive coter, because all unskilled individuals have the same preferences for $\tau$ (and $b$ ). Hence, when the decisive voter is unskilled, then we unambiguously conclude that aging downscales the size of the welfare state. But when the decisive voter is a skilled individual, then the change in the identity of the decisive voter as a result of aging (she is now less able) works in the direction of raising $\tau$ (and $b$ ). This is why $d \tau_{0} / d n$ cannot be signed a priori when the decisive voter is a skilled individual.
} 


\section{CESifo Working Paper Series}

(for full list see www.cesifo.de)

976 Assar Lindbeck, An Essay on Welfare State Dynamics, July 2003

977 Henrik Jordahl and Luca Micheletto, Optimal Utilitarian Taxation and Horizontal Equity, July 2003

978 Martin D. D. Evans and Richard K. Lyons, Are Different-Currency Assets Imperfect Substitutes?, July 2003

979 Thorsten Bayindir-Upmann and Frank Stähler, Market Entry Regulation and International Competition, July 2003

980 Vivek Ghosal, Firm and Establishment Volatility: The Role of Sunk Costs, Profit Uncertainty and Technological Change, July 2003

981 Christopher A. Pissarides, Unemployment in Britain: A European Success Story, July 2003

982 Wolfgang Buchholz, Richard Cornes, and Wolfgang Peters, On the Frequency of Interior Cournot-Nash Equilibria in a Public Good Economy, July 2003

983 Syed M. Ahsan and Panagiotis Tsigaris, Choice of Tax Base Revisited: Cash Flow vs. Prepayment Approaches to Consumption Taxation, July 2003

984 Campbell Leith and Jim Malley, A Sectoral Analysis of Price-Setting Behavior in US Manufacturing Industries, July 2003

985 Hyun Park and Apostolis Philippopoulos, Choosing Club Membership under Tax Competition and Free Riding, July 2003

986 Federico Etro, Globalization and Political Geography, July 2003

987 Dan Ariely, Axel Ockenfels and Alvin E. Roth, An Experimental Analysis of Ending Rules in Internet Auctions, July 2003

988 Paola Conconi and Carlo Perroni, Self-Enforcing International Agreements and Domestic Policy Credibility, July 2003

989 Charles B. Blankart and Christian Kirchner, The Deadlock of the EU Budget: An Economic Analysis of Ways In and Ways Out, July 2003

990 M. Hasham Pesaran and Allan Timmermann, Small Sample Properties of Forecasts from Autoregressive Models under Structural Breaks, July 2003 
991 Hyun Park, Apostolis Philippopoulos and Vangelis Vassilatos, On the Optimal Size of Public Sector under Rent-Seeking competition from State Coffers, July 2003

992 Axel Ockenfels and Alvin E. Roth, Late and Multiple Bidding in Second Price Internet Auctions: Theory and Evidence Concerning Different Rules for Ending an Auction, July 2003

993 Pierre Salmon, The Assignment of Powers in an Open-ended European Union, July 2003

994 Louis N. Christofides and Chen Peng, Contract Duration and Indexation in a Period of Real and Nominal Uncertainty, July 2003

995 M. Hashem Pesaran, Til Schuermann, Björn-Jakob Treutler, and Scott M. Weiner, Macroeconomic Dynamics and Credit Risk: A Global Perspective, July 2003

996 Massimo Bordignon and Sandro Brusco, On Enhanced Cooperation, July 2003

997 David F. Bradford, Addressing the Transfer-Pricing Problem in an Origin-Basis X Tax, July 2003

998 Daniel Gros, Who Needs Foreign Banks?, July 2003

999 Wolfram Merzyn and Heinrich W. Ursprung, Voter Support for Privatizing Education: Evidence on Self-Interest and Ideology, July 2003

1000 Jo Thori Lind, Fractionalization and the Size of Government, July 2003

1001 Daniel Friedman and Donald Wittman, Litigation with Symmetric Bargaining and TwoSided Incomplete Information, July 2003

1002 Matthew Clarke and Sardar M. N. Islam, Health Adjusted GDP (HAGDP) Measures of the Relationship Between Economic Growth, Health Outcomes and Social Welfare, July 2003

1003 Volker Grossmann, Contest for Attention in a Quality-Ladder Model of Endogenous Growth, August 2003

1004 Marcel Gérard and Joan Martens Weiner, Cross-Border Loss Offset and Formulary Apportionment: How do they affect multijurisdictional firm investment spending and interjurisdictional tax competition?, August 2003

1005 Burkhard Heer, Nonsuperneutrality of Money in the Sidrauski Model with Heterogeous Agents, August 2003

1006 V. Anton Muscatelli, Piergiovanna Natale, and Patrizio Tirelli, A Simple and Flexible Alternative to the Stability and Growth Pact Deficit Ceilings. Is it at hand?, August 2003

1007 Reto Foellmi and Josef Zweimüller, Inequality and Economic Growth: European Versus U.S. Experiences, August 2003 
1008 James S. Costain and Michael Reiter, Business Cycles, Unemployment Insurance, and the Calibration of Matching Models, August 2003

1009 Marco Runkel, Optimal Contest Design when the Designer's Payoff Depends on Competitive Balance, August 2003

1010 Donald O. Parsons, Torben Tranaes and Helene Bie Lilleør, Voluntary Public Unemployment Insurance, August 2003

1011 Rüdiger Pethig and Andreas Wagener, Profit Tax Competition and Formula Apportionment, August 2003

1012 Johan Willner, Privatisation and Public Ownership in Finland, August 2003

1013 Seppo Kari and Jouko Ylä-Liedenpohja, Taxation and Valuation of International Real Investments, August 2003

1014 James Heckman, Rosa Matzkin and Lars Nesheim, Simulation and Estimation of Hedonic Models, August 2003

1015 Biswa N. Bhattacharyay, Towards a Macro-Prudential Leading Indicators Framework for Monitoring Financial Vulnerability, August 2003

1016 J. Stephen Ferris and Stanley L. Winer, Searching for Keynes: With Application to Canada, 1870-2000, August 2003

1017 Massimo Bordignon, Luca Colombo and Umberto Galmarini, Fiscal Federalism and Endogenous Lobbies' Formation, August 2003

1018 Annette Alstadsæter, The Dual Income Tax and Firms' Income Shifting through the Choice of Organizational Form and Real Capital Investments, August 2003

1019 Peter Fredriksson and Bertil Holmlund, Optimal Unemployment Insurance Design: Time Limits, Monitoring, or Workfare?, August 2003

1020 Kashif S. Mansori, Following in their Footsteps: Comparing Interest Parity Conditions in Central European Economies to the Euro Countries, August 2003

1021 Christoph Borgmann and Matthias Heidler, Demographics and Volatile Social Security Wealth: Political Risks of Benefit Rule Changes in Germany, August 2003

1022 Kjell Erik Lommerud, Bjørn Sandvik and Odd Rune Staume, Good Jobs, Bad Jobs and Redistribution, August 2003

1023 Patrick Karl O'Brien, The Governance of Globalization: The Political Economy of Anglo-American Hegemony, 1793-2003, September 2003

1024 Antonio Ciccone and Giovanni Peri, Skills' Substitutability and Technological Progress: U.S. States 1950-1990, September 2003 
1025 Bjørn Sandvik, Optimal Taxation and Normalisations, September 2003

1026 Massimo Bordignon and Gilberto Turati, Bailing Out Expectations and Health Expenditure in Italy, September 2003

1027 José A. Herce, Namkee Ahn, Ricard Génova, and Joaquín Pereira, Bio-Demographic and Health Aspects of Ageing in the EU, September 2003

1028 John Komlos and Marieluise Baur, From the Tallest to (One of) the Fattest: The Enigmatic Fate of the American Population in the $20^{\text {th }}$ Century, September 2003

1029 Stefan Napel and Mika Widgrén, Bargaining and Distribution of Power in the EU's Conciliation Committee, September 2003

1030 Kai Li and Dale J. Poirier, Relationship Between Maternal Behavior During Pregnancy, Birth Outcome, and Early Childhood Development: An Exploratory Study, September 2003

1031 Ivar Ekeland, James J. Heckman, and Lars Nesheim, Identifcation and Estimation of Hedonic Models, September 2003

1032 Kjetil Bjorvatn and Alexander W. Cappelen, Decentralization and the Fate of Minorities, September 2003

1033 Lars-Erik Borge and Jørn Rattsø, The Relationships Between Costs and User Charges: The Case of a Norwegian Utility Service, September 2003

1034 Maureen Were and Nancy N. Nafula, An Assessment of the Impact of HIV/AIDS on Economic Growth: The Case of Kenya, September 2003

1035 A. Lans Bovenberg, Tax Policy and Labor Market Performance, September 2003

1036 Peter Birch Sørensen, Neutral Taxation of Shareholder Income: A Norwegian Tax Reform Proposal, September 2003

1037 Roberta Dessi and Sheilagh Ogilvie, Social Capital and Collusion: The Case of Merchant Guilds, September 2003

1038 Alessandra Casarico and Carlo Devillanova, Capital-skill Complementarity and the Redistributive Effects of Social Security Reform, September 2003

1039 Assaf Razin and Efraim Sadka, Privatizing Social Security Under Balanced-Budget Constraints: A Political-Economy Approach, September 2003 